\title{
Language Management in a Multinational Workforce: The Knowledge Worker Perspective ${ }^{1}$
}

\begin{abstract}
Organisations recruiting knowledge workers worldwide face a considerable challenge with regard to the choice of corporate language. The use of English as a lingua franca is often perceived as the most obvious option. However, there may be good arguments for using the host country language even in cases where the language in question is relatively small and the English skills of the local population are high. Our paper reports on the results of a study of a Nordic organisation that has chosen the local language as its corporate language. We investigate the implications for the employees' professional and social identity and also discuss the language ideology underlying this choice. The study is based on both interviews and a survey conducted among both local and international members of the organisation ${ }^{2}$
\end{abstract}

\section{Introduction}

The 21st century has seen a dramatic increase in the number of linguistically diverse organisations, as labour mobility creates workforces hailing from various national backgrounds. One of the consequences of this development is the need to solve the communicative issues that arise from a workforce that do not share a first language.

Empirical research in this field indicates that many organisations resort to ad hoc solutions with regard to solving communicative issues in linguistically diverse settings. From a management perspective introducing English for this purpose may be perceived as a pragmatic solution. The English used in communicative situations where the parties do not share their first language is increasingly referred to as English as a lingua franca (ELF). ELF may be a prerequisite for communication to take place, and works as a contact language (Jenkins 2007). The description of ELF focuses on communicative effectiveness and accommodation skills rather than narrow notions of correctness linked to native English varieties, and "enables its users to express themselves more freely without having to conform to norms which represent the sociocultural identity of other people" (Howatt/Widdowson 2004: 361). The concept of ELF may thus serve to describe the usage of non-native speakers who are language users "in their own right" rather than being conceptualised as "defective" native speakers (Jenkins et al 2011: 284). For the present group of knowledge workers, being able to express themselves using ELF is a requirement for having an international career.

However, the challenges of communicating when the workforce do not share a first language are often underestimated. It should be noted that language issues did not come to the fore in management research until the mid-1990s including a number of metastudies that provide synopses of the issue of language in international business (see Marschan et al 1997, Marschan-Piekkari et al. 1999, Harzing/Feely 2008, Piekkari/Tietze 2012, Harzing/Pudelko 2013, Gunnarsson 2014,

1 The present article is part of NHH's FOCUS (Future-oriented corporate solutions) research programme.

2 We would like to thank our anonymous reviewers for their valuable input to our article.

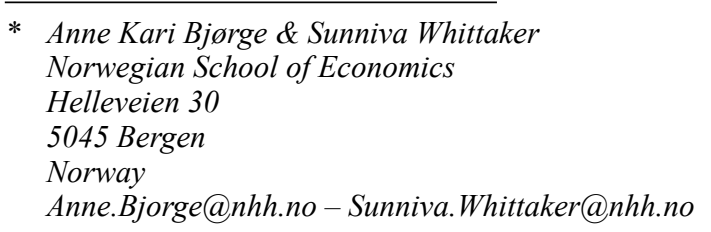


Bjørge/Whittaker 2014 and Piekkari et al. 2014). The topic is only recently entering the management textbook domain, e.g. as an aspect of international human resource management (Piekkari/ Tietze 2012), or from a language management perspective (Bjørge/Whittaker 2014). Its relative novelty in management education may serve to explain why many organisations do not have a language policy as part of their strategy.

\subsection{Language management}

The subject area of language management refers to strategies regarding the choice of functional language for international organisations or national organisations with a multilingual workforce, and builds on the substantial amount of research that has been carried out respecting language differences and choice of corporate language in multinational companies (MNCs). A comprehensive overview of the global situation is found in Harzing/Pudelko (2013), who establish country clusters based on the relative importance of the local language worldwide combined with the level of English language skills, viz. Asian countries, Continental European countries, Anglophone countries, and Nordic countries. The latter are said to be characterised by excellent English language skills and English being widely used for business purposes; in addition to the local language being of little importance on a world-wide scale (Harzing/Pudelko 2013: 89). According to their findings, the corporate language in Nordic MNCs is always English, never the language of the headquarters, demonstrating "the irrelevance of Scandinavian languages...in international business, and ultimately, the high proficiency of managers in Scandinavian countries" (Harzing/ Pudelko 2013: 94).

On this background one would assume that the language management issue in the Nordic countries would be dealt with by introducing English as the corporate language, and that the local languages would only play a secondary role in a corporate context. Previous research into Nordic companies (Marschan et al. 1997, Marschan-Piekkari et al. 1999, Louhiala-Salminen et al. 2005, Charles 2007, Lauring 2008, Tange/Lauring 2009, Lauring/Selmer 2010, Piekkari et al. 2014) has modified this picture, by demonstrating that local language issues are also relevant in a Nordic context even when English has been chosen as the corporate language, e.g. with respect to power relations. However, no studies have looked into organisations where the local Nordic language has been chosen for this purpose.

In our paper we will explore the language management situation in an organisation in the Nordic cluster which has chosen the host country language as their corporate language. Our approach will also take into account the fact that the global labour market includes a growing professional class whom we will refer to as international knowledge workers. These are highly educated people whose professional identity is linked to developing or using knowledge and whose competence is attractive in the global labour market. They may have positions in management or research, where it is required to have English proficiency at a professional level. The ease of acquiring the local language may be related to first language background, but this issue is beyond the scope of this paper.

If the host country language is of low importance worldwide due to small domestic populations and little or no colonial past, the international worker is only in exceptional cases expected to have any prior knowledge of it when accepting a position. If the local population in addition has a high level of English skills it may be assumed that a rudimentary understanding of the local language is sufficient. A case in point is Norway, which at the time of writing (2015) recruits a substantial number of knowledge workers, in particular when it comes to working in oil and gasrelated industries.

\subsection{Theoretical background}

Our study will be based on theories of language ideology and social identity/self-categorisation theory, which are briefly described below. 
General theories of language ideology are concerned with how assumptions and beliefs about language are reflected in language structures and language use (Woolard 1998). As pointed out by Kroskrity (2004) conceptions about language may be explicitly articulated or embedded in communicative practice. This author underscores that rationalisations about language tend to be context bound and constructed from the sociocultural experience of the speaker. Not surprisingly, many studies of language ideology focus on languages in contact and how various social factors determine the choice of language in specific settings. Although such studies have primarily been concerned with use and practices in linguistically diverse nations, theories on language ideologies have also proven useful to describe the choice of language in companies with a linguistically diverse work force. In her study of language choice and language ideology in an international company in Denmark, Lønsmann (2014: 108) refers to the "one nation, one language" ideology, which has been demonstrated to be influential when it comes to language choice in Denmark. The host country language acquires a symbolic meaning for its native speakers, who may feel that their language is threatened by domain loss. It may thus create negative feelings if an international employee fails to make the effort to learn (Piekkari/Tietze 2012: 554, Lønsmann 2014: 92). In general, locals start out by being willing to accommodate the newcomer linguistically, but this willingness has been found to diminish over time (Lønsmann 2014).

Social identity theory relates to "that part of the individuals' self-concept which derives from their knowledge of their membership of a social group (or groups) together with the value and emotional significance attached to that membership" (Tajfel 1981: 255). Language is a powerful factor with regard to the formation of social identity groups (Harzing/Feely 2008, Lauring 2008, Tange/Lauring 2009, Lønsmann 2014). Lack of local language proficiency may be a barrier to career advancement (Lønsmann 2014, Piekkari et al. 2014), and Piekkari/Tietze (2012: 560) call for more research into "language as a glass ceiling", and "to move beyond the study of adjustment and focus on the effect of language on expatriate performance". Knowledge workers are ambitious people who have been successful in their home countries, they belong to a global educational elite, and are at the top of their profession. Ward et al (2001: 52) point to the fact that people who are highly successful in their own country may find it particularly frustrating to feel inadequate in a new cultural setting. Failing to learn the local language may thus affect the worker's professional identity, and if proficiency is linked to job performance it may also affect career prospects. From a social identity perspective, learning the local language is important to develop relationships with host nationals and avoid social exclusion (Piekkari/Tietze 2012: 554), while mastering informal communication is a major integrational factor (Charles 2007). Fluency in the host country language has been demonstrated to have "a significant positive direct effect on interaction adjustment" (Reiche/Harzing 2011: 208). As recruiting knowledge workers is costly, focusing on the role of linguistic proficiency in integration should be a management priority.

Combined, the two theoretical approaches described above should provide valuable insights into the consequences of choosing the host nation language as corporate language and how such a strategy can be effectively implemented.

\subsection{Research questions}

Our paper will address the following research questions;

1. How do the perspectives of the international knowledge workers compare to those of Norwegian employees with respect to language ideology? (3.1)

2. Does choosing the local language as the corporate language impact on the workers' social and professional identity? $(3.2 / 3,3)$

3. How does the use of the local language compare with using English as a corporate language? 


\section{Material/Method}

The research questions presented in the previous section will be dealt with using empirical data from one organisation that fits the scenario described above: an organisation with the employee segment we are interested in, i.e. knowledge workers, and which has chosen the local language as its corporate language notwithstanding the organisation's international employer profile. The organisation in question is a major Norwegian research and development organisation. For reasons of anonymity, the company name has been replaced by RDO, an acronym for Research and Development Organisation. Our study was conducted using both interviews and survey material. In the following we will briefly describe the organisation under investigation and discuss the research methods we have applied.

\subsection{Research setting}

RDO, whose internationalisation process started around 2007, recruits knowledge workers on a global scale, and at the time of writing (2015) employs a workforce that hails from 70 national backgrounds. The company has received a prestigious national prize for its efforts to promote a diverse working environment. According to senior management having Norwegian as the corporate language is a consensus-based decision, but not formally set out in any company policy document; nor is it referred to in the job adverts. However, English has a powerful auxiliary role, and it is clear that the organisation could not function on the basis of Norwegian alone. English is the language of research publication, and is a requirement for employment for international employees. Documentation that is vital for the organisation such as HR material, strategy documents and RDO's code of ethics are produced in both languages. Decisions regarding which information is to be given in both English and Norwegian is made at a managerial level.

RDO offers both basic and more advanced language courses in company time for their employees and their families. The number of courses offered is a function of the needs of the organisation at any given time. Different factors come into play when it comes to bringing international workers up to a satisfactory linguistic level, i.e. enabling them to communicate orally and in writing in both informal and professional settings. The management recognises that an employee's first language is a factor when it comes ease of learning. Also some internationals have acquired Norwegian skills prior to their employment at RDO. There is therefore no predefined set of courses international workers must undergo and the pace at which employees learn the language varies considerably, not only due to their aptitude but also to work constraints. In addition to language courses RDO also finances courses addressing integration into Norwegian society and culture.

RDO's policy for language management thus combines the use of Norwegian as a corporate language with a pragmatic use of English. This makes it a suitable candidate for exploring the research questions outlined above.

\subsection{Method}

Our study is based on two types of empirical data. First interviews with a total of 22 members of the organisation were conducted in the spring of 2014. The interviews were followed up with a survey sent out to 265 employees in the autumn of 2014.

Both the interviews and the survey had a broader scope than the topic for this article as the research questions dealt with here form one part of a larger research project including other aspects of language management. In the following we will briefly describe the methods used.

\subsubsection{Interviews}

Seven semi-structured interviews were carried out at RDO, containing questions relating to the employees' experience with and attitude to the use of Norwegian as a corporate language, both in professional and in social contexts. The questions were prepared in advance in the form of an 
interview guide but a certain amount of latitude was given to the interviewees allowing them to dwell on their personal experiences and to discuss the questions among themselves.

Two senior management representatives were interviewed individually whereas the other interviews took the form of focus groups. Norwegian and international employees were placed in separate groups. The members of each group belonged to one of the following professions: communication managers, HR managers, research managers and researchers. The number of members in each focus group ranged from one (due to no shows) to five. The sample included both male (M) and female $(\mathrm{F})$ interviewees:

\begin{tabular}{|l|l|l|l|}
\hline Interview & Participants/Gender & Profession & Time \\
\hline RDO1 & $1(\mathrm{M})$ & HR management & $1 \mathrm{~h} 20 \mathrm{~min}$ \\
\hline RDO3 & $3(2 \mathrm{M}, 1 \mathrm{~F})$ & Communication management & $50 \mathrm{~min}$ \\
\hline RDO6 & $4(\mathrm{~F})$ & HR management & $53 \mathrm{~min}$ \\
\hline RDO7 & $3(2 \mathrm{M}, 1 \mathrm{~F})$ & Research management & $1 \mathrm{~h} 05 \mathrm{~min}$ \\
\hline
\end{tabular}

Table 1. Norwegian nationals

\begin{tabular}{|l|l|l|l|}
\hline Interview & Participants/Gender & Profession & Time \\
\hline RDO2 & $5(3 \mathrm{~F}, 2 \mathrm{M})$ & Researchers & $1 \mathrm{~h} 17 \mathrm{~min}$ \\
\hline RDO4 & $5(4 \mathrm{M}, 1 \mathrm{~F})$ & Researchers & $1 \mathrm{~h} 06 \mathrm{~min}$ \\
\hline RDO5 & $1(\mathrm{M})$ & Researchers & $37 \mathrm{~min}$ \\
\hline
\end{tabular}

Table 2. International researchers

The interviews with Norwegian nationals were carried out in Norwegian, while the ones with international researchers were carried out in English. The 11 internationals came from eight different nationalities (Brazil, France, Germany, Ireland, Italy, Russia, the UK and the US). Those who did not have English as their first language had a good functional command of the language, allowing them to communicate effectively.

The interviews were sound recorded, and relevant passages were transcribed, using a broad transcription approach, i.e. a verbatim description excluding pausing and backchannelling. Norwegian language passages have been translated into English. For transcription conventions, see Appendix 2.

\subsubsection{Questionnaire}

The questionnaire was elaborated after the interviews had taken place and was influenced by the insights obtained through the interviews. The questionnaire was sent out to researchers and administrative staff in RDO, who could choose between an English and a Norwegian variant and yielded a response rate of $34 \%$. The questions pertaining to the issues under investigation in this article were both close-ended (answers on a five-point Likert scale) and open-ended, allowing us to harvest both quantitative and qualitative data. The open-ended questions were thematically related to those asked during the interviews thus providing a more solid empirical basis for our observations. The questions used in the survey are included in Appendix 3.

The material reported on here refers to 90 participants; 16 of whom responded in English and 74 who responded in Norwegian. The latter group included 18 non-Norwegian employees. This means that we had 56 Norwegian respondents and 34 non-Norwegians ('Other'). When reporting results, we use the dichotomy Norwegian-Other. Where relevant, we report on differences between those who responded using the English language questionnaire (EQ respondents), and 
those who responded using the Norwegian language questionnaire (NQ respondents), as the two groups report different levels of proficiency (see Appendix 1).

\begin{tabular}{|l|l|l|l|l|}
\hline $\begin{array}{l}\text { Questionnaire } \\
\text { language }\end{array}$ & $\begin{array}{l}\text { English } \\
\text { (EQ) }\end{array}$ & \multicolumn{2}{|l|}{ Norwegian (NQ) } & TOTAL \\
\hline $\begin{array}{l}\text { Nationality of } \\
\text { respondents }\end{array}$ & 'Other' & 'Other' & Norwegian & \\
\hline $\begin{array}{l}\text { Number of } \\
\text { respondents }\end{array}$ & 16 & 18 & 56 & 90 \\
\hline
\end{tabular}

Table 3. Questionnaire respondents

\section{Results}

In the following we present the results from our interviews and the questionnaire relating to language ideology (3.1), language and social identity (3.2), and language and professional identity (3.3). Section 3.3 is further subdivided into performance issues (3.3.1) and access to information (3.3.2).

\subsection{Language ideology}

Questions relating to language ideology were posed both in the interviews and in the survey with a view to identifying the rationalisations behind the choice of the local language as a corporate language, and to determining to what extent these rationalisations were accepted by both Norwegian and international employees. We were particularly interested in finding out whether the "one nation, one language" ideology described by Lønsmann (2014: 108) was prevalent in RDO.

\subsubsection{Interview results}

In the interviews, representatives from senior management were asked to explain the rationale behind choosing the local language as the corporate language. It was made clear from the outset that not having Norwegian as 'the working language' had never been on the agenda, and that the decision was widely accepted in the organisation: M1: it is our impression that most people think it's right to keep Norwegian as the working language
... my impression is that many people think that this is the right and an OK thing to do (RDO1)

Three arguments in favour of employing the local language were presented. The first and the most predominant argument was linked to the integration of international employees in the organisation and in society in general, including the integration of their families. While using English is recognised as acceptable in a short-term perspective, learning the local language is considered critical in order to avoid a high labour turnover:

M1: if you do not learn Norwegian you do not become a part of Norwegian society ... you ought to be able to talk to your neighbours, go shopping (RDO1)

M1: international employees who master Norwegian are happier and stay for longer in RDO (RDO1)

RDO pays for comprehensive Norwegian courses for employees and their spouses:

M1: this is also a success because if you have a spouse sitting at home who doesn't speak Norwegian the employee will disappear in the course of two to three years (RDO1)

Some internationals, however, found it difficult to cope with language courses in addition to a strenuous workload, particularly when they had reached a certain level: 
F3: they do provide norskkurs (i.e. Norwegian classes) which is good you get to a certain level and then your workload is so heavy you just like I think it's that level 2 you get so that you can speak Norwegian fairly well and then you get to a point where it's just too much I've seen this with other foreigners your workload is so much that you just can't do any more Norwegian courses as a person can only give so much (RDO2)

Others stated that courses could be more adapted to their work situation, e.g. by being intensive and run at weekends, and by focusing explicitly on specific professional domains.

The second argument was that the use of the local language was considered important to the wellbeing of the local workforce. According to one interviewee, however, the number of Norwegians who did not favour using English in meetings was declining.

The third argument concerns the interface with important local clients who expect to be able to communicate in the local language. Lack of proficiency may limit the workers' ability to build a local project portfolio:

F1: you try turning up at Statens veivesen or Kystverket and speak English - not a great success, no (RDO7)

Finally, one of our interviewees stated that proficiency was required for a career move into line management.

However, the picture is not entirely static but also includes a certain amount of ambivalence, and one interviewee expressed a realisation that this situation would not necessarily be the same in the future:

M1: I think there will be more focus on bilingualism (RDO1)

It will thus be clear that in the day-to-day activity at RDO English has the status of an auxiliary language. In addition, English is recognised as the language of publication and international projects, and signals membership in the international research community.

\footnotetext{
M1: the share of meetings held in English is increasing, but this concerns the academic meetings ... a lot of written material at RDO is in English ... EU research for instance, all international research and publications ... in this respect we are a bit different from many others because there's a lot of English as the working language (RDO1)
}

The general impression from the interviews is that there is no explicit challenge to RDO's corporate language policy, but a certain amount of frustration concerning its implementation on the part of the internationals.

\subsubsection{Questionnaire results}

The issue of language ideology was dealt with in an open-ended question where the respondents were asked to give their comments relating to RDO's strategy for using Norwegian as a corporate language. It is interesting to note that 49 out of the 90 respondents chose not to answer this question. The remaining 41 adhered to the strategy to varying extents. The responses could be broadly divided into four categories according to content. The responses were categorised by both of the authors separately and the inter rater reliability was $100 \%$. 


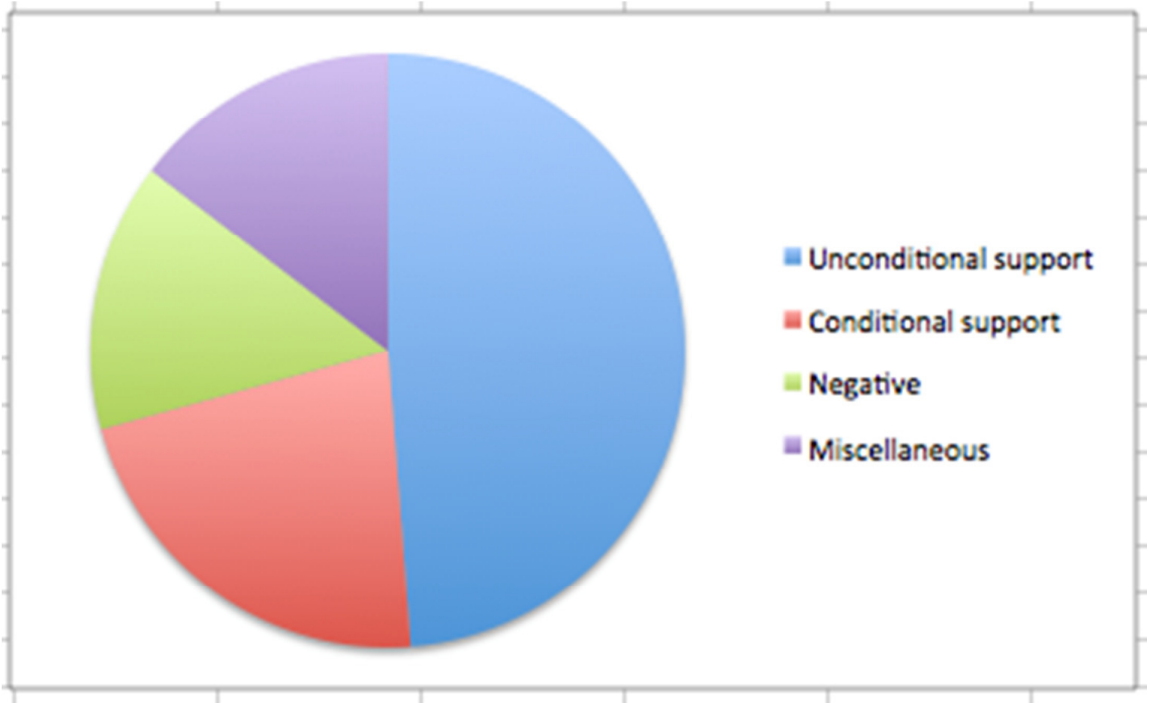

Figure 1. Comments on Norwegian as a corporate language ( $n=41 ; 12$ Other and 29 Norwegian)

Those expressing unconditional support (15 Norwegian, 5 Other) found the policy to be 'important', 'good', 'OK', and 'the only sensible option'. Supporting arguments refer to national identity, access to information, flexibility, inclusion and employee retention. This category also includes respondents who were positive to the policy but sceptical about its implementation, as the latter point of view is not pertinent to the investigation.

Similar arguments were used by those expressing conditional support (5 Norwegian, 4 Other), adding the importance of customer contact and maintaining good internal relations in RDO. However, key contextual factors are mentioned that need to be taken into account, such as lack of proficiency, adverse effect on recruitment and employee turnover, in addition to the linguistic requirements of different projects. English is recognised as the language of publication and international contexts, for conveying important information, and avoiding misunderstandings. Respondents support a flexible approach, one concluding that "You can easily live in Norway without having Norwegian". Key objections refer to confusion, lack of clarity and follow-up, and fitting Norwegian courses into a busy schedule. One respondent even stated that some colleagues do not get the information they need to do their job, which is described as 'unfortunate'. As this respondent did not explicitly reject the language policy, the response is classified as conditional.

Those who are explicitly negative (4 Norwegian and 2 Other) claim that the choice of the local language as corporate language led to a lack of flexibility and had an adverse effect on employees' integration into the research community, both internationally and in the RDO context. They also pointed to the challenges learning a new language posed to new and temporary employees. Finally, the Miscellaneous category includes two respondents (both Norwegian) who did not know that Norwegian was the corporate language, two who commented on lack of implementation and clarity, one who just found the policy to be problematic, and one (Other) who claimed that linguistic problems were due to the lack of proficiency in English among staff.

\subsection{Language and social identity}

Social identities come to the fore in various arenas in the workplace, and possessing the linguistic proficiency to function in social contexts is important to develop a sense of belonging (Charles 2007, Tange/Lauring 2009, Lønsmann 2014). In the following we report on how the choice of language impacts on central events in the RDO workplace. 


\subsubsection{Interview results}

It transpired from the interviews that the lunch break was a key social arena for Norwegians and internationals alike. Both groups stressed the significance of being in their linguistic comfort zone in this setting:

F1: when we have our lunch we don't speak English - the small talk is important (RDO6)

F1: We Norwegians go together with the ones we are located with generally, we do that, I realise that I should have joined that table [i.e., but no I feel that they are speaking English and I feel that I can't do that in my leisure time (RDO6)

Internationals have similar feelings, but being in minority they could feel excluded and unable to express their personality in contexts where Norwegian was spoken:

F1: I'm already outside my comfortable zone I'm speaking my second language all the time and for them it is also a second language and they don't want to make effort often you are sitting and they are talking something funny and so are laughing (RDO2)

F2: I switch my personality because (in my own language) I make a lot of jokes but here I am more serious because I can not understand the jokes and it's hard to make some

[All: $\mathrm{mhm}(\mathrm{xx})$

F2: somehow I begin to feel different

All: yeah] (RDO2)

Feelings of exclusion could lead to withdrawing from the lunch break as a social arena:

M1: one thing that I find is very difficult on the integration part like you know if I at the lunch table if the conversation is in Norwegian ...

F3: I don't take lunch with my colleagues for that reason

M2: no I don’t I stay in my office

F3: well I connect with a lot of other foreigners at lunch ... but I don't like sitting in the lunch room with when ... many people are speaking Norwegian ...

M1: it's difficult to follow

F3: ... when there's a lot of people it's very difficult to follow

[All: yeah

F3: in a loud chatty room] so I think that ... socially I kind of get a bit frozen out in a way

M1: it's very complicated ... it's a lot of effort for you to understand and you cannot get all the things so you cannot jump into the conversation (RDO2)

The interviewees in RDO2 were particularly open and forthcoming about these issues:

F1: you see we're very interested in these questions because you see it's painful for everyone (RDO2)

Others deliberately used the lunch break as an arena for learning the language by forbidding the use of English, and with good results:

M1: there are some who have explicitly stated that they are not allowed to speak English during the break... their Norwegian proficiency improved hugely (RDO1) 
There were also reports of clustering according to native language, or internationals vs Norwegians. Native speakers of English reported that their usage depended on whether they interacted with other native speakers or with non-native speakers of English.

Outside work successful socialising relates to family and leisure activities. Internationals also find it easier to relate to Norwegian nationals who have experience from living abroad, presumably because the latter have had to adapt during their careers.

M1: you get terribly tired ... in addition you have to relate to customers, colleagues, (science) ... it may take six years, it is incredibly tiring, just going shopping is a challenge (RDO7)

\subsubsection{Questionnaire results (for details, see Appendix 3)}

In the following we report the main results for the questionnaire items relating to social identity (for details, see Appendix 3):

\section{Q6.3/26.3: To what extent do you speak Norwegian in social contexts (lunch breaks, small talk)}

This question was answered by both Norwegians and Other. While $41.2 \%$ of Other reported that they spoke Norwegian in the $<40 \%$ band, this only applied to $14.3 \%$ of the Norwegians. However, if we subdivide the Other group according to EQ and NQ respondents, we find that NQ respondents report similar figures to the Norwegians, viz. $11.2 \%$. This may be linked to Norwegian proficiency, as NQ Other respondents report a higher proficiency level than EQ respondents (see Appendix 1).

\section{Q15.3/36.3: I find it demanding to speak Norwegian in social contexts (lunch breaks, small talk)}

This question was answered by Other only. While $56.2 \%$ of the EQ respondents agreed or strongly agreed with this statement, this only applied to $22.2 \%$ of the NQ respondents. Also, $61.1 \%$ of the latter ticked Strongly disagree, which only applied to $6.3 \%$ of the EQ respondents.

\section{Q12.1/32.1: RDO's choice of Norwegian as a corporate language is important with regard to the integration of international employees}

This question was answered by both Norwegians and Other. While $68.4 \%$ of the former (strongly) agreed, the latter yielded $50 \%$ for this view. If we subdivide the Other group, we find that $43.7 \%$ of the EQ and $55.5 \%$ of the NQ respondents chose this option. In contrast, $43.8 \%$ of the EQ and $27.8 \%$ of the NQ respondents (strongly) disagreed, so proficiency may play a role. It thus appears that Norwegians are more positive when it comes to corporate policy in this respect.

\section{Q17.6/38.6: Good Norwegian language proficiency is important for my well-being at work}

This question was answered by Other only. As $62.5 \%$ of EQ and $58.8 \%$ of NQ respondents chose (strongly) agree for this statement the two groups have similar views in this respect. Also, nobody ticked Strongly disagree.

\subsection{Language and professional identity}

Professional identity is closely linked to successful job performance (Feeling/Harzing 2003, Bjørge/Whittaker 2014, Piekkari et al. 2014). In the following, we report on the relevance of the corporate language for some performance issues, access to information, and career prospects. 


\subsubsection{Performance issues}

\section{Interview results}

The internationals stated that having to use Norwegian slows you down, and may make it difficult to participate, particularly when you are new employee. This creates pressure when being expected to perform right from the start in very demanding jobs, and some feel that allowances are not made for not having enough Norwegian. Lack of small talk proficiency is also mentioned as a competitive advantage for the host nationals in rapport-building with customers.

Presentations are generally less problematic, and having slides in English while presenting in Norwegian works well. Professional genres like negotiations and legal language, however, are seen as more demanding, and as a topic that should be taught to international workers. Union work is a case in point, as this is entirely in Norwegian.

From the Norwegian perspective it is first of all pointed out that the international workers represent an elite, and that the company only recruits the best. It is perceived that the internationals participate less in meetings, but linguistic strategies adopted include that questions can be put in English, while the answer may be in Norwegian. English is always acceptable if it is a question of avoiding misunderstandings. Norwegian presenters vary in the extent to which they insist on a 'Norwegian only'-policy as a pedagogical device.

\section{Questionnaire results: speaking}

For self-reporting on Norwegian proficiency (speaking), see Appendix 1.

\section{Q6.1/26.1: To what extent do you speak Norwegian in [contact with clients]}

This question was answered by both Other and Norwegians. $32.3 \%$ of the former and $66 \%$ of the latter belonged in the $>60 \%$ segment, which shows a marked predominance for the Norwegians. If we subdivide the Other group, we find $18.8 \%$ for the EQ and $44.4 \%$ for the NQ respondents, confirming the link between language proficiency and contact with clients. Also, we found that $75 \%$ of the EQ respondents belonged in the $<20 \%$ segment, which may even indicate nil.

\section{Q15.1/36.1: I find it demanding to speak Norwegian in [contact with clients]}

This question was only answered by Other. In this group, 53.3\% of the EQ and $29.4 \%$ of the NQ respondents (strongly) agree with this statement. Conversely, $6.7 \%$ of the EQ and $64.7 \%$ of the NQ (strongly) disagree, indicating a link to proficiency.

\section{Q6.2/26.2: To what extent do you speak Norwegian in [meetings]}

This question was answered by both Other and Norwegians. $32.4 \%$ of the former chose the $<20 \%$ segment, which, interestingly, was also the choice for $8.9 \%$ of the Norwegians. If we subdivide the Other group, we find that $62.5 \%$ of the EQ and $5.6 \%$ of the NQ respondents chose this segment, while $13 \%$ of the EQ and $72.2 \%$ of the NQ respondents belonged in the $>60 \%$ segment.

\section{Q15.2/36.2: I find it demanding to speak Norwegian in [meetings]}

This question was only answered by Other. $53.4 \%$ of the EQ and $22.2 \%$ of the NQ (strongly) agree with this statement. Conversely, $26.7 \%$ of the EQ disagree (none strongly disagree), while $16.7 \%$ of the NQ respondents disagree, and $38.9 \%$ strongly disagree. The group is thus clearly polarised with respect to this statement, indicating the impact of proficiency.

\section{Questionnaire results: writing}

For self-reporting on proficiency (writing), see Appendix 1. 


\section{Q8.1/28.1: How many of the [emails] you write are written in Norwegian?}

This question was answered by both Other and Norwegians. $32.3 \%$ of the former and $3.6 \%$ of the latter chose the $<20 \%$ segment. Conversely, $35.3 \%$ of the former and $57.1 \%$ of the latter belonged in the $>60 \%$ segment. In the Other group, we find $62.5 \%$ EQ and $5.5 \%$ NQ respondents in the $<20 \%$ segment, and $6.25 \%$ EQ and $61.1 \%$ of the NQ respondents in the $>60 \%$ segment.

\section{Q8.2/28.2: How many of the [reports] you write are written in Norwegian?}

This question was answered by both Other and Norwegians. $76.5 \%$ of the former and $46.4 \%$ of the latter chose the $<20 \%$ segment. In the Other group, $87.5 \%$ of the EQ and $66 \%$ of the NQ chose the $<20 \%$ segment. It would thus appear that for the Other group, writing reports in Norwegian is not the majority option.

Q8.3/28.3: How many of the [minutes] you write are written in Norwegian? (Other) This question was answered by both Other and Norwegians. $73.6 \%$ of the former and $21.5 \%$ of the latter reported in the $<20 \%$ segment. In the Other group, $87.5 \%$ of the EQ and $61.1 \%$ of the NQ respondents belonged in this segment.

It will be clear that the overwhelming proportion of job texts written by the internationals are not in Norwegian, presumably in English, particularly reports and minutes. We also note the extensive use of English among the Norwegians, and that the email format is where Norwegian is most likely to be used by the Other category, particularly the EQ respondents.

\section{Questionnaire results: reading}

\section{Q9.1/30.1: How many of the [emails] you read are written in Norwegian?}

This question was answered by both Other and Norwegians. Only $11.8 \%$ of the former and $5.4 \%$ of the latter chose the $<20 \%$ category, and $44.1 \%$ of the former and $55.4 \%$ of the latter chose the $>60 \%$ category. This indicates that the email is a form where Norwegian has a strong position, which also applies for the EQ respondents in the Other category, as only $18.75 \%$ belonged to the $<20 \%$ category.

\section{Q9.2/30.2: How many of the [reports] you read are written in Norwegian?}

This question was answered by both Other and Norwegians. $58.9 \%$ of the former and $44.6 \%$ of the latter chose the $<20 \%$ category, and for the Other group EQ respondents reported $62.5 \%$ and the NQ respondents $55.5 \%$. For the $>60 \%$ group, EQ had $0 \%$ and NG $11.1 \%$. It will thus be clear that reports are to a great extent not read in Norwegian, but presumably in English

\section{Q9.3/30.3: How many of the [minutes] you read are written in Norwegian?}

This question was answered by both Other and Norwegians. $44.1 \%$ of the former and $14.3 \%$ of the latter chose the $<20 \%$ category, and it would appear the all respondents read at least some minutes in Norwegian. As for the Other category, $50 \%$ of the EQ and $38.9 \%$ of the NQ chose the $<20 \%$ category. On the other hand, there is a certain exposure to minutes in Norwegian even for the EQ category.

It would thus appear that while Norwegian plays an important role as information input, a substantial amount of information is conveyed in other languages, presumably English. The highest proportion of Norwegian is found in emails. 


\subsubsection{Access to information}

\section{Interview results}

The international workers tended to define themselves as being at the receiving end of the information flow. They state that all critical information is available in English, and that the administration helps out with queries. There is, however, a general desire to have more information in English, in particular when it comes to company websites.

Our international interviewees reported on a number of coping strategies when confronted with Norwegian messages, emails being a case in point:

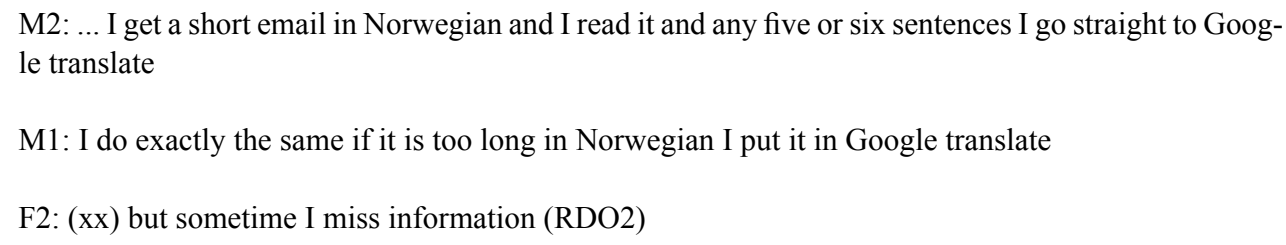

Another strategy is to sit it out and hope for the best:

M2: if it's important someone will call me back (RDO2)

One interviewee said she no longer used this strategy, indirectly implying that it had backfired. There was also an understanding that even when the main point was understood, there might be more to the message:

M1: I feel I get the information I need but maybe I would get more if it was more transparent (RDO5)

The same interviewee reported sitting in on a two-day training session where he was the only one who did not understand Norwegian, and reported learning some language despite not understanding much, concluding that language 'is a true barrier'.

Meetings are an important arena both when it comes to performance (3.3.1) and access to information, but when the meeting is in Norwegian this may happen:

F2: when we have a meeting I cannot speak so much and because I don't understand what the person
said I ask something that has already been said or which has been discussed for ten minutes

All:@@(RDO2)

One management representative found it hard to check whether the information conveyed was understood by the internationals:

F1: Asian employees ... important to check understanding, as respect for authority may keep them from stating that they do not understand (RDO7)

F1: Even if someone confirms that he has understood the contents it turns out that he has not, despite the fact that you use English because English is not their first language (RDO7)

\section{Questionnaire results}

\section{Q17.3/38.3: I have missed important information because it was only available in Norwegian}

This question was only answered by the Other category. Of the EQ respondents, $50 \%$ chose Strongly agree or Agree for this question, while this only applied to $5.6 \%$ of the NQ respondents; of whom $50 \%$ chose Strongly disagree. 


\section{Q17.4/38.4: I have missed interesting information because it was only available in Norwegian}

This question was also only answered by the Other category, and the EQ respondents had $50 \%$ for Strongly agree or Agree. The proportion of NQ respondents who chose Agree here was higher than for the question on important information, viz. $22.2 \%$.

\subsubsection{Career prospects/linguistic glass ceiling}

\section{Interview results}

In our interviews, it became clear that learning Norwegian was definitely a factor to take into account when you were planning for a career in the company:

M1: if you have ambition and want to progress in the company you will have a problem if you don't speak Norwegian (RDO5)

M1: management needs Norwegian (RDO5)

Norwegian was seen as necessary to expand your network, develop your career, and to engage in union activity.

M1: there's a part of the meeting which is social connection and then we see that Norwegian will help (RDO5)

M2: to maintain a good relation with the client you need Norwegian (RDO4)

There is also the issue of competing for attractive projects with Norwegians on their home turf:

M1: you find that you are in competition with Norwegians, of course it's also we're working together but competition exists also so I will say that Norwegians also take advantage of this situation - that's normal it's part of the game so in this regard you have to take your responsibility (RDO5)

A good command of the language was seen as particularly important for those who want to climb the management ladder, as a line manager will have to communicate with employees at all levels in the organisation, in addition to dealing with HRM and union-related issues. However, the issue was clearly perceived as a language issue only, and it was stressed that everyone - irrespective of national background - had the same career prospects.

Despite this, the requirement of learning Norwegian is not a part of the job specifications, but only communicated - but not specified in detail - in the job interview. From the Norwegian perspective, it is pointed out that it is necessary to learn the language to be happy working for the organisation. It also turned out that one international worker had his contract terminated because his Norwegian was so poor that he could not be integrated in his department's project portfolio:

\footnotetext{
F1: we sent one home ... after his trial period and said that we can't do this he worked on his Norwegian and everything ... they come from abroad highly educated $\mathrm{PhD}$ top expertise one of the best when it comes to publishing but integrating someone like this in the project portfolio we have today is too difficult (RDO7)
}

When it comes to producing research there is less of a problem, as the language of research and publication is English. Language requirements are thus to a certain extent dependent on your job role, and the degree to which you do applied research.

It was also pointed out that the international worker is being challenged at the social and the professional level simultaneously, and that not everyone does this successfully:

F1: when I headed the other department where there were few foreigners I think I only heard success stories... when I came to the department I am now heading I saw that it was not only success stories they have problems speaking Norwegian, they have problems getting projects, they struggle to integrate they may struggle socially... and we keep banging them over the head with Norwegian language requirements there are many stories behind these percentages (RDO7) 
Not having Norwegian thus limits career prospects, and may be described as constituting a glass ceiling.

\section{Q12.6/32.6: Good Norwegian proficiency is vital for career advancement at [RDO]}

\begin{tabular}{|l|l|l|l|l|l|l|}
\hline Nationality & $\begin{array}{l}\text { Strongly } \\
\text { agree }\end{array}$ & Agree & $\begin{array}{l}\text { Neither } \\
\text { agree nor } \\
\text { disagree }\end{array}$ & Disagree & $\begin{array}{l}\text { Strongly } \\
\text { disagree }\end{array}$ & Total \\
\hline Other & $25 \%$ & $34 \%$ & $22 \%$ & $16 \%$ & $3 \%$ & $\mathrm{n}=32$ \\
\hline Norwegian & $9 \%$ & $35 \%$ & $17 \%$ & $28 \%$ & $11 \%$ & $\mathrm{n}=54$ \\
\hline
\end{tabular}

Table 4. Proficiency and career advancement

We note the high figures for agreement with this statement, particularly among the internationals. The Norwegians, on the other hand, have higher figures for disagreement.

\section{Discussion}

In this section we will discuss our findings in light of the three research questions presented in the introduction to this article.

\subsection{Research question 1: How do the perspectives of the international knowledge workers compare to those of Norwegian employees with respect to language ideology?}

Our findings show that RDO's choice of Norwegian as a corporate language is both ideologically and pragmatically motivated. Senior management's statement that this is the "right thing to do" can be ascribed to a "one nation one language ideology", and speaking Norwegian when in Norway is perceived as the obvious choice. This is in line with the findings of Lønsmann (2014). However, our study demonstrates that the use of the local language is also pragmatically motivated. Speaking the local language is perceived as a key factor for integration both in the workplace and in the local community, and integration is in return decisive for RDO's ability to retain international knowledge workers. The choice of the local language is thus perceived as having a clear impact on the organisation's overall performance. At the same time the use of the local language and English in various settings clearly reflects its dual identity as both a local and an international player. Interaction with clients and other local stakeholders requires the use of the local language, and for international knowledge workers to contribute to the organisation's activities in the geographical area, learning the local language is crucial. For its role as an international player, geography is of lesser relevance.

RDO competes with other organisations internationally and its success is based solely on the competence and performance of the workers. The choice of the local language as the corporate language signals the emphasis placed on its role as a local player. Our findings show that for international knowledge workers, there may be a conflict between contributing locally and contributing on the international playing field. Learning the local language is time-consuming and may be to the detriment of one's contribution to the organisation's international activities. At the same time, being able to contribute both locally and internationally is a prerequisite for internal career advancement. Ability to speak the local language is thus a source of power (Marschan-Piekkari 1999). Workers who do not have this ability are likely to contribute less locally, and as a consequence be less firmly anchored geographically. They may well perceive themselves as nomadic knowledge workers, moving across organisations and geographical areas in order to advance in their careers. In this context, two different ideologies are at play: the local language is viewed as 
a source of power within the organisation and English as a source of power in the global research community. These assumptions are not challenged by our informants, but the strategies they use to maneuver in this landscape vary.

\subsection{Research question 2: Does choosing the local language as the corporate language impact on the workers' social and professional identity?}

Even when English is the corporate language in a multinational company, mastering the company owners' language has been found to be a source of power, as it gives privileged access to information through formal and informal channels (Marschan-Piekkari et al. 1999). The same has been found to apply in a domestic context with a multinational workforce (Lønsmann 2014). Our findings demonstrate that RDO's policy creates a unique role for the host country language that is ideologically as well as pragmatically motivated. Both social and professional success is linked to level of proficiency, and failing to learn may be perceived as a powerful signal when it comes to integration and a long-term commitment to RDO. Locals may thus feel that it is in some sense 'right' to use the local language when interacting with internationals, as it helps to develop their proficiency, and ultimately integration in the local cultural context.

In social contexts, English is employed in an auxiliary role, where Norwegians and internationals alike may feel that they are outside their linguistic comfort zone. This may even apply to native speakers of English, who have to adapt their language when interacting with non-native speakers. We also identified some evidence of co-nationals communicating in their native language, i.e. language clustering (Tange/Lauring 2009). This provides an arena for expressing social skills like humour and small talk, genre repertoires that were experienced as a challenge in one's second or third language. Others insisted on using the corporate language, some to the extent of prohibiting the use of English. However, operating outside one's linguistic comfort zone was by many felt to be exhausting, and as leading to feelings of isolation and exclusion. Tange/ Lauring (2009: 219) refers to the "withdrawal of organisational members" in cases where the informal communication takes place in a "non-native, corporate language". In RDO, this is not only evidenced by feelings of isolation in social contexts, but also by employees reporting that they take their lunch break in their offices, some even communicating with their families by phone. It should however be noted that national identity is not an absolute, but may have been subject to deconstruction through international experience. Thus, some internationals reported that locals with such a background were generally easier to relate to due to their expatriate experience.

As for the professional aspect, corporate language proficiency is a career asset, and nationals are perceived as being advantaged when it comes to building a customer portfolio and climbing the managerial ladder. This is universally perceived as a question of linguistic proficiency only, and nationality per se is not in itself a deciding factor. However, this situation is regarded as creating a linguistic glass ceiling for internationals. As a consequence, the choice of corporate language may make RDO a less attractive employer for international applicants with management ambitions. For research-related tasks, however, international workers without a good command of the local language may be successful provided they are assigned to international projects where communication with the client will take place in English.

Another aspect linked to linguistic proficiency is access to information, as employees miss important or interesting information if it is only available in the corporate language. While we did not identify any parallel information networks (Feely/Harzing 2003), one of the internationals did mention that he expected to be contacted if he did not respond to written messages, which implies some kind of socially-based channel. Emails in the corporate language were submitted to google translate to get the gist, which can be regarded as an instance of "thin communication" (Tange/ Lauring 2009) as any subtleties and social aspects are likely to be lost. Assuming that internationals will be adequately informed by using emails in the corporate language thus appears to be a practice that could backfire. This also applies to meetings, where internationals without proficiency in the corporate language may take part while understanding nothing or very little. 
The professional identity of international knowledge workers is closely linked to successful job performance. From the above it will be clear that proficiency in the corporate language is essential for building a project portfolio and for line management, which both require language-related social skills like networking and rapport management. As the corporate language will be in a privileged position, proficiency is a source of power.

\subsection{Research question 3: How does the use of the local language compare with using English as a corporate language?}

Irrespective of which language is chosen, the implementation of a corporate language policy depends on strategic planning, without which linguistic decisions will be situationally determined on an ad hoc basis. However, choosing the local language rather than English distorts the power structure in favour of the locals, e.g. in terms of access to information and career paths.

The internationals in our study all have a functional command of the language in keeping with the description of English as a lingua franca (Jenkins 2007). If English were the corporate language, there would be a greater incentive for the locals to communicate in this medium, making for a more even playing field. If not, the motivation to build a shared communicative platform is weaker, as the corporate language has an ideologically and pragmatically motivated status that makes it 'right' to communicate in this language. However, English is used extensively as an auxiliary language in order to assure the smooth running of the organisation.

\section{Conclusion}

Our study demonstrates that in linguistically diverse working environments pragmatic considerations will necessarily be taken into account even in cases where one language is given the status of corporate language. Choosing the host country language as opposed to English, however, has implications for the power relation between local and international workers, as some career paths within the organisation are closely linked to proficiency in the local language. Our study indicates that international knowledge workers face two options: embracing the local language and thereby enhancing their career prospects in the organisation, or using their time in the organisation to strengthen their international attractiveness, in which case their incentive to learn the local language will be weaker. Within the former category some may even fail to acquire the linguistic proficiency required for career advancement, thus finding themselves up against a linguistic glass ceiling. As the host country language is the organisations's preferred language of socialisation, there is less incentive for the hosts to accommodate the internationals by using English, as this may be justified as being detrimental to their linguistic development and hence careers. This strategy may, however, lead to withdrawal from social arenas on the part of the internationals, and ultimately reduce their motivation to remain in the country. In this respect the management's strategy of using the local language as a corporate language to retain international knowledge workers is only partially successful.

Some weaknesses of this study must be pointed out. First of all, the size of the sample is limited. Nor have we addressed the significance of the international workers' linguistic background in relation to the ease of acquisition of the corporate language. Indeed, in our investigation of the ideological and social and professional identity issues, the international workers have been considered as belonging to one uniform group. However, by focusing specifically on the knowledge worker perspective the present study provides insights into how linguistic proficiency in the host country language impacts on the social and professional identity of an employee segment with liberty to exercise a global choice of employment. It is reasonable to assume that our findings will be of relevance for other companies with the same employer profile. We have focused on a case where the local language is employed as the corporate language, but regardless choice of corporate language there will be a need for auxiliary strategies to ensure communication. For those who regard a global career based on English as unproblematic it may modify the picture and create 
more realistic expectations as to the role of the host language in the country clusters where they may take up employment.

As mentioned in our introduction, the body of research relating to language management has increased over the past decade. However, given the variety of demographic, linguistic and socioprofessional factors that may impact on the success of a given language management strategy, there is clearly a need for more empirical research. In the present study, interview data have been triangulated with survey data. It may be worth considering whether other methods, e.g. experimental research might provide useful insights into the implications of using a local language versus a lingua franca.

\section{References}

Bjørge, Anne Kari/Whittaker, Sunniva 2014: Language management. In Gehrke, Bettina/Claes, Marie-Thérèse. (eds.), Global leadership practices, 51-66. Palgrave MacMillan.

Charles, Mirjalisa 2007: Language matters in global communication. In Journal of Business Communication 44, 3 , 260-282.

Feely, Alan/Harzing, Anne-Wil 2003: Language management in multinational companies. In Cross Cultural Management 10, 2, 37-52.

Gunnarsson, Britt Louise 2014: Multilingualism in European workplaces. In Multilingua 33(1-2), 11-33.

Harzing, Anne-Wil/Pudelko, Markus 2013: Language competencies, policies and practices in multinational corporations. In Journal of World Business, 48, 87-97.

Harzing, Anne-Wil/Feely, Alan J. 2008: The language barrier and its implications for HQ-subsidiary relationships. In Cross Cultural Management: An International Journal 15, 1, 49-61.

Howatt, Anthony P. R/Widdowson, Henry George: 2004: A history of English language teaching. 2nd ed. Oxford: Oxford University Press.

Jenkins, Jennifer 2007: English as a Lingua Franca: Attitude and identity. Oxford University Press.

Jenkins, Jennifer/Cogo, Alessia/Dewey, Martin 2011: Review of developments in research into English as a lingua franca. In Language teaching 44, 3, 281-315.

Kroskrity, Paul .V. 2004: Language ideologies. In Duranti, Alessandro. (ed), A companion to linguistic anthropology. Blackwell.

Lauring, Jakob 2008: Rethinking social identity theory in international encounters: Language use as a negotiated object for identity making. In International Journal of Cross Cultural Management 8, 343-361.

Lauring, Jakob/Selmer, Jan. 2010: Multicultural organizations: common language and group cohesion. In International Journal of Cross Cultural Management 10, 3, 267-284.

Lønsmann, Dorthe 2014: Linguistic diversity in the international workplace. In Multilingua 33(1-2), 89-117.

Louhiala-Salminen, Leena/Charles, Mirjalisa/Kankaanranta, Anna 2005: English as a lingua franca in Nordic corporate mergers: two case companies. In English for Specific Purposes 24/4: 401-421.

Marschan, Rebecca/Welch, Denice/Welch, Lawrence 1997: Language: The forgotten factor in multinational management. In European Management Journal 15, 5, 591-598.

Marschan-Piekkari, R., Welch, Denice and Welch, Lawrence 1999: In the shadow: the impact of language on structure, power and communication in the multinational. In International Business Review 8, 421-440.

Piekkari, Rebecca/Tietze, Susanne 2012: Language and international human resource management. In Stahl, G. et al., Handbook of research in international human resource management, 549-565. Edward Elgar.

Piekkari, Rebecca/Welch, Denice/Welch, Lawrence 2014: Language in international business. Edware Elgar.

Reiche, Sebastian/Harzing, Anne-Wil 2011: International assignments. In Harzing, Anne-Wil/Pinnington, A.H., International human resource management. Sage, 185-214.

Schieffelin, Bambi, Woolard, Kathryn A. and Kroskrity, Paul V. (eds) 1998: Language ideologies: practice and theory. Oxford University Press.

Tajfel, Henry 1981: Human groups and social categories: Studies in social psychology. Cambridge University Press.

Tange, Hanne/Lauring, Jakob 2009: Language management and social interaction within the multilingual workplace. In Journal of Communication Management 13, 3, 218-232.

Ward, Colleen/Bochner, Steven/Furnham, Adrian 2001: The psychology of culture shock. 2nd ed. Routledge.

Woolard, Kathryn A. 1998: Introduction: Language ideology as a field of enquiry. In Bambi Schieffelin et al., 3-47. 
APPENDIX 1 Norwegian proficiency. 'Other' respondents

$\mathrm{EQ}=$ English questionnaire

$\mathrm{NQ}=$ Norwegian questionnaire

EQ respondents $(n=16)$

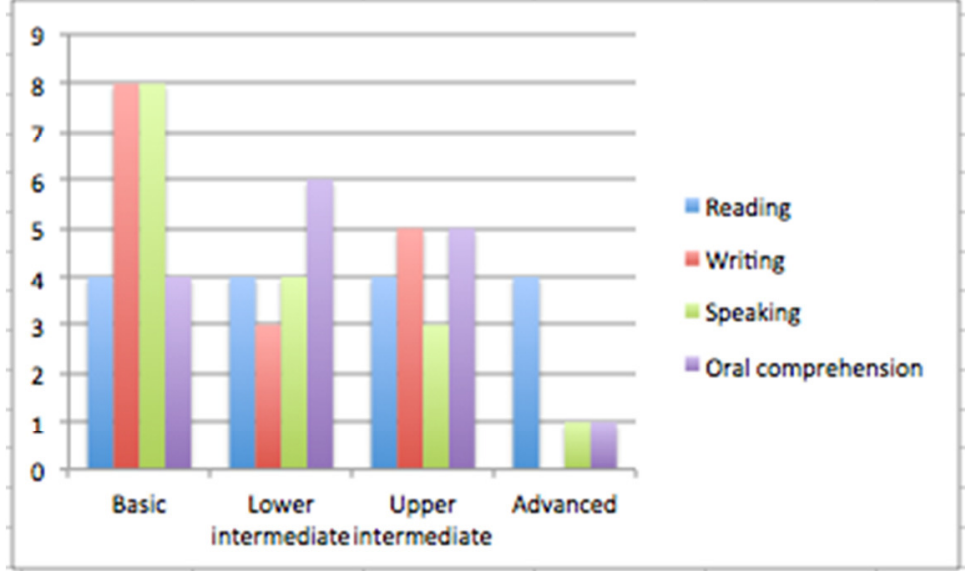

NQ respondents $(n=18)$

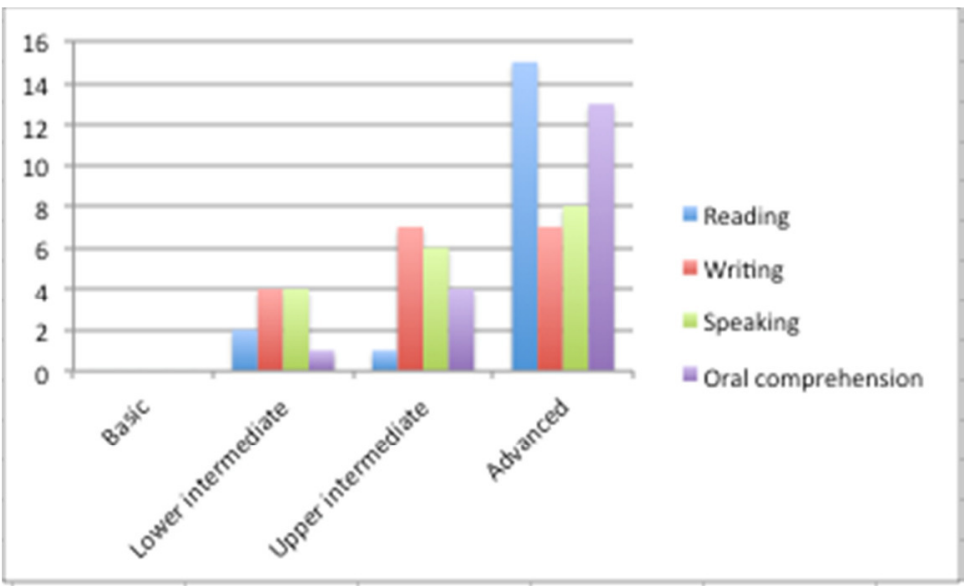




\section{APPENDIX 2. Transcription conventions}

Speakers

\section{$\mathrm{F}$ \\ $\mathrm{M}$}

All

Utterances

Uncertain transcription

Unintelligible speech

Laughter

Overlapping speech

Word(s) omitted female (e.g. F1)

male (e.g. M1)

all participants speaking at once

speaker reference + space + utterance

(text)

$(\mathrm{xx})$

@@

[Speaker(s) text] (e.g. [F1 text M1 text])

\section{APPENDIX 3. Questionnaire results}

\subsubsection{Language and social identity}

Q6.3/26.3: To what extent do you speak Norwegian in social contexts (lunch breaks, small talk)

\begin{tabular}{|l|r|r|r|r|r|r|}
\hline Nationality & \multicolumn{1}{|l|}{$0-20 \%$} & \multicolumn{1}{l|}{$20-40 \%$} & $40-60 \%$ & $60-80 \%$ & $80-100 \%$ & \multicolumn{1}{l|}{ Total } \\
\hline Other & $32.4 \%$ & $8.8 \%$ & $20.6 \%$ & $17.6 \%$ & $20.6 \%$ & $\mathrm{n}=34$ \\
\hline Norwegian & $3.6 \%$ & $10.7 \%$ & $10.7 \%$ & $35.7 \%$ & $39.3 \%$ & $\mathrm{n}=56$ \\
\hline
\end{tabular}

\begin{tabular}{|l|r|r|r|r|r|r|}
\hline Other & \multicolumn{1}{|l|}{$-20 \%$} & \multicolumn{1}{l|}{$20-40 \%$} & \multicolumn{1}{l|}{$40-60 \%$} & $60-80 \%$ & $80-100 \%$ & \multicolumn{1}{l|}{ Total } \\
\hline EQ respondents & $62.5 \%$ & $12.5 \%$ & $18.7 \%$ & $6.3 \%$ & $0 \%$ & $\mathrm{n}=16$ \\
\hline NQ respondents & $5.6 \%$ & $5.6 \%$ & $22.2 \%$ & $27.7 \%$ & $38.9 \%$ & $\mathrm{n}=18$ \\
\hline TOTAL Other & $32.4 \%$ & $8.8 \%$ & $20.6 \%$ & $17.6 \%$ & $20.6 \%$ & $\mathrm{n}=34$ \\
\hline
\end{tabular}

Q15.3/36.3: I find it demanding to speak Norwegian in social contexts (lunch breaks, small talk) Answered by Other only

\begin{tabular}{|l|r|r|r|r|r|r|}
\hline Other & \multicolumn{1}{l|}{$\begin{array}{l}\text { Strongly } \\
\text { agree }\end{array}$} & Agree & $\begin{array}{l}\text { Neither } \\
\text { agree nor } \\
\text { disagree }\end{array}$ & Disagree & $\begin{array}{l}\text { Strongly } \\
\text { disagree }\end{array}$ & Total \\
\hline EQ respondents & $18.7 \%$ & $37.5 \%$ & $12.5 \%$ & $25 \%$ & $6.3 \%$ & $\mathrm{n}=16$ \\
\hline NQ respondents & $11.1 \%$ & $11.1 \%$ & $5.6 \%$ & $11.1 \%$ & $61.1 \%$ & $\mathrm{n}=18$ \\
\hline TOTAL Other & $14.7 \%$ & $23.5 \%$ & $8.8 \%$ & $17.7 \%$ & $35.3 \%$ & $\mathrm{n}=34$ \\
\hline
\end{tabular}


Q12.1/32.1: RDO's choice of Norwegian as a corporate language is important with regard to the integration of international employees

\begin{tabular}{|l|r|r|r|r|r|r|}
\hline Nationality & $\begin{array}{l}\text { Strongly } \\
\text { agree }\end{array}$ & Agree & $\begin{array}{l}\text { Neither } \\
\text { agree nor } \\
\text { disagree }\end{array}$ & Disagree & $\begin{array}{l}\text { Strongly } \\
\text { disagree }\end{array}$ & Total \\
\hline Other & $23.5 \%$ & $26.5 \%$ & $14.7 \%$ & $23.5 \%$ & $11.8 \%$ & $\mathrm{n}=34$ \\
\hline Norwegian & $37.0 \%$ & $31.4 \%$ & $16.7 \%$ & $9.3 \%$ & $5.6 \%$ & $\mathrm{n}=54$ \\
\hline
\end{tabular}

\begin{tabular}{|l|r|r|l|r|r|r|}
\hline Other & \multicolumn{1}{l|}{$\begin{array}{l}\text { Strongly } \\
\text { agree }\end{array}$} & \multicolumn{1}{l|}{ Agree } & $\begin{array}{l}\text { Neither } \\
\text { agree nor } \\
\text { disagree }\end{array}$ & Disagree & $\begin{array}{l}\text { Strongly } \\
\text { disagree }\end{array}$ & Total \\
\hline EQ respondents & $12.5 \%$ & $31.2 \%$ & $12.5 \%$ & $25 \%$ & $18.8 \%$ & $\mathrm{n}=16$ \\
\hline NQ respondents & $33.3 \%$ & $22.2 \%$ & $16.7 \%$ & $22.2 \%$ & $5.6 \%$ & $\mathrm{n}=18$ \\
\hline TOTAL Other & $23.5 \%$ & $26.5 \%$ & $14.7 \%$ & $23.5 \%$ & $11.8 \%$ & $\mathrm{n}=34$ \\
\hline
\end{tabular}

Q17.6/38.6: Good Norwegian language proficiency is important for my well-being at work Answered by Other only

\begin{tabular}{|l|r|r|r|r|r|r|}
\hline Other & $\begin{array}{l}\text { Strongly } \\
\text { agree }\end{array}$ & Agree & $\begin{array}{l}\text { Neither } \\
\text { agree nor } \\
\text { disagree }\end{array}$ & Disagree & $\begin{array}{l}\text { Strongly } \\
\text { disagree }\end{array}$ & \multicolumn{1}{l|}{ Total } \\
\hline EQ respondents & $18.75 \%$ & $43.75 \%$ & $18.75 \%$ & $18.75 \%$ & 0 & $\mathrm{n}=16$ \\
\hline NQ respondents & $29.4 \%$ & $29.4 \%$ & $23.5 \%$ & $17.7 \%$ & 0 & $\mathrm{n}=17$ \\
\hline TOTAL Other & $24.2 \%$ & $36.4 \%$ & $21.2 \%$ & $18.2 \%$ & $0 \%$ & $\mathrm{n}=33$ \\
\hline
\end{tabular}

\subsection{Language and professional identity}

\subsubsection{Performance issues: speaking}

Q6.1/26.1: To what extent do you speak Norwegian in [contact with clients]

\begin{tabular}{|l|r|r|r|r|r|r|}
\hline Nationality & \multicolumn{1}{|l|}{$0-20 \%$} & \multicolumn{1}{l|}{ Th-40\% } & \multicolumn{1}{c|}{$40-60 \%$} & $60-80 \%$ & $80-100 \%$ & \multicolumn{1}{l|}{ Total } \\
\hline Other & $44.1 \%$ & $6 \%$ & $17.6 \%$ & $17.6 \%$ & $14.7 \%$ & $\mathrm{n}=34$ \\
\hline Norwegian & $5.4 \%$ & $12.5 \%$ & $16.1 \%$ & $30.3 \%$ & $35.7 \%$ & $\mathrm{n}=56$ \\
\hline
\end{tabular}

\begin{tabular}{|l|r|r|r|r|r|r|}
\hline Other & \multicolumn{1}{|l|}{$0-20 \%$} & \multicolumn{1}{l|}{$20-40 \%$} & \multicolumn{1}{l|}{$40-60 \%$} & $60-80 \%$ & $80-100 \%$ & \multicolumn{1}{l|}{ Total } \\
\hline EQ respondents & $75 \%$ & $6.25 \%$ & $0 \%$ & $12.5 \%$ & $6.25 \%$ & $\mathrm{n}=16$ \\
\hline NQ respondents & $16.7 \%$ & $5.6 \%$ & $33.3 \%$ & $22.2 \%$ & $22.2 \%$ & $\mathrm{n}=18$ \\
\hline TOTAL Other & $44.1 \%$ & $6 \%$ & $17.6 \%$ & $17.6 \%$ & $14.7 \%$ & $\mathrm{n}=34$ \\
\hline
\end{tabular}


Q15.1/36.1 : I find it demanding to speak Norwegian in [contact with clients] Answered by Other only

\begin{tabular}{|l|r|r|l|r|r|r|}
\hline Other & \multicolumn{1}{l|l}{$\begin{array}{l}\text { Strongly } \\
\text { agree }\end{array}$} & \multicolumn{1}{l|}{ Agree } & $\begin{array}{l}\text { Neither } \\
\text { agree nor } \\
\text { disagree }\end{array}$ & Disagree & $\begin{array}{l}\text { Strongly } \\
\text { disagree }\end{array}$ & Total \\
\hline EQ respondents & $33.3 \%$ & $20 \%$ & $40 \%$ & $6.7 \%$ & $0 \%$ & $\mathrm{n}=15$ \\
\hline NQ respondents & $5.9 \%$ & $23.5 \%$ & $5.9 \%$ & $23.5 \%$ & $41.2 \%$ & $\mathrm{n}=17$ \\
\hline TOTAL Other & $18.7 \%$ & $21.9 \%$ & $21.9 \%$ & $15.6 \%$ & $21.9 \%$ & $\mathrm{n}=32$ \\
\hline
\end{tabular}

Q6.2/26.2: To what extent do you speak Norwegian in [meetings]

\begin{tabular}{|l|r|r|r|r|r|r|}
\hline Nationality & \multicolumn{1}{|c|}{$0-20 \%$} & \multicolumn{1}{c|}{$20-40 \%$} & $40-60 \%$ & $60-80 \%$ & $80-100 \%$ & \multicolumn{1}{l|}{ Total } \\
\hline Other & $32.4 \%$ & $2.9 \%$ & $20.6 \%$ & $29.4 \%$ & $14.7 \%$ & $\mathrm{n}=34$ \\
\hline Norwegian & $8.9 \%$ & $8.9 \%$ & $23.3 \%$ & $33.9 \%$ & $25 \%$ & $\mathrm{n}=56$ \\
\hline
\end{tabular}

\begin{tabular}{|l|r|r|r|r|r|r|}
\hline Other & \multicolumn{1}{|l|}{$0-20 \%$} & \multicolumn{1}{l|}{$20-40 \%$} & \multicolumn{1}{l|}{ T0-60\% } & $60-80 \%$ & $80-100 \%$ & \multicolumn{1}{l|}{ Total } \\
\hline EQ respondents & $62.5 \%$ & $6.25 \%$ & $18.75 \%$ & $6.25 \%$ & $6.25 \%$ & $\mathrm{n}=16$ \\
\hline NQ respondents & $5.6 \%$ & $0 \%$ & $22.2 \%$ & $50 \%$ & $22.2 \%$ & $\mathrm{n}=18$ \\
\hline TOTAL Other & $32.4 \%$ & $2.9 \%$ & $20.6 \%$ & $29.4 \%$ & $14.7 \%$ & $\mathrm{n}=34$ \\
\hline
\end{tabular}

Q15.2/36.2 : I find it demanding to speak Norwegian in [meetings] Answered by Other only

\begin{tabular}{|l|r|r|r|r|r|r|}
\hline Other & \multicolumn{1}{l|}{$\begin{array}{l}\text { Strongly } \\
\text { agree }\end{array}$} & \multicolumn{1}{l|}{ Agree } & $\begin{array}{l}\text { Neither } \\
\text { agree nor } \\
\text { disagree }\end{array}$ & Disagree & $\begin{array}{l}\text { Strongly } \\
\text { disagree }\end{array}$ & Total \\
\hline EQ respondents & $26.7 \%$ & $26.7 \%$ & $20 \%$ & $26.7 \%$ & 0 & $\mathrm{n}=15$ \\
\hline NQ respondents & $5.5 \%$ & $16.7 \%$ & $22.2 \%$ & $16.7 \%$ & $38.9 \%$ & $\mathrm{n}=18$ \\
\hline TOTAL Other & $15.2 \%$ & $21.2 \%$ & $21.2 \%$ & $21.2 \%$ & $21.2 \%$ & $\mathrm{n}=33$ \\
\hline
\end{tabular}

\section{Performance issues: writing}

Q8.1/28.1: How many of the [emails] you write are written in Norwegian?

\begin{tabular}{|l|r|r|r|r|r|r|}
\hline Nationality & \multicolumn{1}{|l|}{$0-20 \%$} & $20-40 \%$ & $40-60 \%$ & $60-80 \%$ & $80-100 \%$ & \multicolumn{1}{l|}{ Total } \\
\hline Other & $32.3 \%$ & $11.8 \%$ & $20.6 \%$ & $29.4 \%$ & $5.9 \%$ & $\mathrm{n}=34$ \\
\hline Norwegian & $3.6 \%$ & $17.9 \%$ & $21.4 \%$ & $30.3 \%$ & $26.8 \%$ & $\mathrm{n}=56$ \\
\hline
\end{tabular}

\begin{tabular}{|l|r|r|r|r|r|r|}
\hline Other & \multicolumn{1}{|l|}{$0-20 \%$} & $20-40 \%$ & $40-60 \%$ & $60-80 \%$ & $80-100 \%$ & \multicolumn{1}{l|}{ Total } \\
\hline EQ respondents & $62.5 \%$ & $6.25 \%$ & $25 \%$ & 0 & $6.25 \%$ & $\mathrm{n}=16$ \\
\hline NQ respondents & $5.5 \%$ & $16.7 \%$ & $16.7 \%$ & $55.6 \%$ & $5.5 \%$ & $\mathrm{n}=18$ \\
\hline TOTAL Other & $32.3 \%$ & $11.8 \%$ & $20.6 \%$ & $29.4 \%$ & $5.9 \%$ & $\mathrm{n}=34$ \\
\hline
\end{tabular}


Q8.2/28.2: How many of the [reports] you write are written in Norwegian?

\begin{tabular}{|l|r|r|r|r|r|r|}
\hline Nationality & \multicolumn{1}{|l|}{$0-20 \%$} & \multicolumn{1}{|l|}{$20-40 \%$} & $40-60 \%$ & $60-80 \%$ & $80-100 \%$ & \multicolumn{1}{l|}{ Total } \\
\hline Other & $76.5 \%$ & $14.7 \%$ & $5.9 \%$ & $0 \%$ & $2.9 \%$ & $\mathrm{n}=34$ \\
\hline Norwegian & $46.4 \%$ & $12.5 \%$ & $7.2 \%$ & $10.7 \%$ & $23.2 \%$ & $\mathrm{n}=56$ \\
\hline
\end{tabular}

\begin{tabular}{|l|r|r|r|r|r|r|}
\hline Other & \multicolumn{1}{|l|}{$0-20 \%$} & $20-40 \%$ & $40-60 \%$ & $60-80 \%$ & $80-100 \%$ & \multicolumn{1}{l|}{ Total } \\
\hline EQ respondents & $87.5 \%$ & $6.25 \%$ & $6.25 \%$ & $0 \%$ & $0 \%$ & $\mathrm{n}=16$ \\
\hline NQ respondents & $66.6 \%$ & $22.2 \%$ & $5.6 \%$ & $0 \%$ & $5.6 \%$ & $\mathrm{n}=18$ \\
\hline TOTAL Other & $76.5 \%$ & $14.7 \%$ & $5.9 \%$ & $0 \%$ & $2.9 \%$ & $\mathrm{n}=34$ \\
\hline
\end{tabular}

Q8.3/28.3: How many of the [minutes] you write are written in Norwegian? (Other)

\begin{tabular}{|l|l|l|l|l|l|l|}
\hline Nationality & $0-20 \%$ & $20-40 \%$ & $40-60 \%$ & $60-80 \%$ & $80-100 \%$ & Total \\
\hline Other & $73.6 \%$ & $2.9 \%$ & $20.6 \%$ & $0 \%$ & $2.9 \%$ & $\mathrm{n}=34$ \\
\hline Norwegian & $21.5 \%$ & $19.6 \%$ & $10.7 \%$ & $19.6 \%$ & $28.6 \%$ & $\mathrm{n}=56$ \\
\hline
\end{tabular}

\begin{tabular}{|l|l|l|l|l|l|l|}
\hline Other & $0-20 \%$ & $20-40 \%$ & $40-60 \%$ & $60-80 \%$ & $80-100 \%$ & Total \\
\hline EQ respondents & $87.5 \%$ & $0 \%$ & $12.5 \%$ & $0 \%$ & $0 \%$ & $\mathrm{n}=16$ \\
\hline NQ respondents & $61 \%$ & $5.6 \%$ & $27.8 \%$ & $0 \%$ & $5.6 \%$ & $\mathrm{n}=18$ \\
\hline TOTAL Other & $73.6 \%$ & $2.9 \%$ & $20.6 \%$ & $0 \%$ & $2.9 \%$ & $\mathrm{n}=34$ \\
\hline
\end{tabular}

\subsubsection{Performance issues: reading}

Q9.1/30.1: How many of the [emails] you read are written in Norwegian?

\begin{tabular}{|l|l|l|l|l|l|l|}
\hline Nationality & $0-20 \%$ & $20-40 \%$ & $40-60 \%$ & $60-80 \%$ & $80-100 \%$ & Total \\
\hline Other & $11.8 \%$ & $11.8 \%$ & $32.3 \%$ & $29.4 \%$ & $14.7 \%$ & $\mathrm{n}=34$ \\
\hline Norwegian & $5.4 \%$ & $19.6 \%$ & $19.6 \%$ & $37.5 \%$ & $17.9 \%$ & $\mathrm{n}=56$ \\
\hline
\end{tabular}

\begin{tabular}{|l|l|l|l|l|l|l|}
\hline Other & $0-20 \%$ & $20-40 \%$ & $40-60 \%$ & $60-80 \%$ & $80-100 \%$ & Total \\
\hline EQ respondents & $18.75 \%$ & $18.75 \%$ & $25 \%$ & $25 \%$ & $12.5 \%$ & $\mathrm{n}=16$ \\
\hline NQ respondents & $5.55 \%$ & $5.55 \%$ & $38.9 \%$ & $33.3 \%$ & $16.7 \%$ & $\mathrm{n}=18$ \\
\hline TOTAL Other & $11.8 \%$ & $11.8 \%$ & $32.3 \%$ & $29.4 \%$ & $14.7 \%$ & $\mathrm{n}=34$ \\
\hline
\end{tabular}

Q9.2/30.2: How many of the [reports] you read are written in Norwegian?

\begin{tabular}{|l|l|l|l|l|l|l|}
\hline Nationality & $0-20 \%$ & $20-40 \%$ & $40-60 \%$ & $60-80 \%$ & $80-100 \%$ & Total \\
\hline Other & $58.9 \%$ & $17.6 \%$ & $17.6 \%$ & $5.9 \%$ & $0 \%$ & $\mathrm{n}=34$ \\
\hline Norwegian & $44.6 \%$ & $17.9 \%$ & $10.7 \%$ & $14.3 \%$ & $12.5 \%$ & $\mathrm{n}=56$ \\
\hline
\end{tabular}

\begin{tabular}{|l|l|l|l|l|l|l|}
\hline Other & $0-20 \%$ & $20-40 \%$ & $40-60 \%$ & $60-80 \%$ & $80-100 \%$ & Total \\
\hline EQ respondents & $62.5 \%$ & $18.75 \%$ & $18.75 \%$ & $0 \%$ & $0 \%$ & $\mathrm{n}=16$ \\
\hline NQ respondents & $55.5 \%$ & $16.7 \%$ & $16.7 \%$ & $11.1 \%$ & $0 \%$ & $\mathrm{n}=18$ \\
\hline TOTAL Other & $58.9 \%$ & $17.6 \%$ & $17.6 \%$ & $5.9 \%$ & $0 \%$ & $\mathrm{n}=34$ \\
\hline
\end{tabular}


Q9.3/30.3: How many of the [minutes] you read are written in Norwegian?

\begin{tabular}{|l|l|l|l|l|l|l|}
\hline Nationality & $0-20 \%$ & $20-40 \%$ & $40-60 \%$ & $60-80 \%$ & $80-100 \%$ & Total \\
\hline Other & $44.1 \%$ & $11.8 \%$ & $26.5 \%$ & $14.7 \%$ & $2.9 \%$ & $\mathrm{n}=34$ \\
\hline Norwegian & $14.3 \%$ & $16.1 \%$ & $23.2 \%$ & $19.6 \%$ & $26.8 \%$ & $\mathrm{n}=56$ \\
\hline
\end{tabular}

\begin{tabular}{|l|l|l|l|l|l|l|}
\hline Other & $0-20 \%$ & $20-40 \%$ & $40-60 \%$ & $60-80 \%$ & $80-100 \%$ & Total \\
\hline EQ respondents & $50 \%$ & $12.5 \%$ & $18.75 \%$ & $18.75 \%$ & $0 \%$ & $\mathrm{n}=16$ \\
\hline NQ respondents & $38.9 \%$ & $11.1 \%$ & $33.3 \%$ & $11.1 \%$ & $5.6 \%$ & $\mathrm{n}=18$ \\
\hline TOTAL Other & $44.1 \%$ & $11.8 \%$ & $26.5 \%$ & $14.7 \%$ & $2.9 \%$ & $\mathrm{n}=34$ \\
\hline
\end{tabular}

\subsubsection{Access to information}

Q17.3/38.3: I have missed important information because it was only available in Norwegian. Answered by Other only

\begin{tabular}{|l|l|l|l|l|l|l|}
\hline Other & $\begin{array}{l}\text { Strongly } \\
\text { agree }\end{array}$ & Agree & $\begin{array}{l}\text { Neither } \\
\text { agree nor } \\
\text { disagree }\end{array}$ & Disagree & $\begin{array}{l}\text { Strongly } \\
\text { disagree }\end{array}$ & Total \\
\hline EQ respondents & $18.75 \%$ & $31.2 \%$ & $18.75 \%$ & $25 \%$ & $6.3 \%$ & $\mathrm{n}=16$ \\
\hline NQ respondents & $0 \%$ & $5.6 \%$ & $22.2 \%$ & $22.2 \%$ & $50 \%$ & $\mathrm{n}=18$ \\
\hline TOTAL Other & $8.8 \%$ & $17.7 \%$ & $20.6 \%$ & $23.5 \%$ & $29.4 \%$ & $\mathrm{n}=34$ \\
\hline
\end{tabular}

Of the 9 who agreed, 8 were NQ respondents; while of the 18 who disagreed, 13 were EQ respondents.

Q17.4/38.4: I have missed interesting information because it was only available in Norwegian. Answered by Other only

\begin{tabular}{|l|r|r|r|r|r|r|}
\hline Other & $\begin{array}{l}\text { Strongly } \\
\text { agree }\end{array}$ & Agree & $\begin{array}{l}\text { Neither } \\
\text { agree nor } \\
\text { disagree }\end{array}$ & Disagree & $\begin{array}{l}\text { Strongly } \\
\text { disagree }\end{array}$ & Total \\
\hline EQ respondents & $25 \%$ & $25 \%$ & $25 \%$ & $25 \%$ & $0 \%$ & $\mathrm{n}=16$ \\
\hline NQ respondents & $0 \%$ & $22.2 \%$ & $16.7 \%$ & $11.1 \%$ & $50 \%$ & $\mathrm{n}=18$ \\
\hline TOTAL Other & $11.8 \%$ & $23.5 \%$ & $20.6 \%$ & $17.6 \%$ & $26.5 \%$ & $\mathrm{n}=34$ \\
\hline
\end{tabular}

